\title{
Bridging the depleted MORB mantle and the continental crust using titanium isotopes
}

\author{
Z. Deng ${ }^{1 *}$, F. Moynier ${ }^{1,2}$, P.A. Sossi ${ }^{1}$, M. Chaussidon ${ }^{1}$
}

Abstract

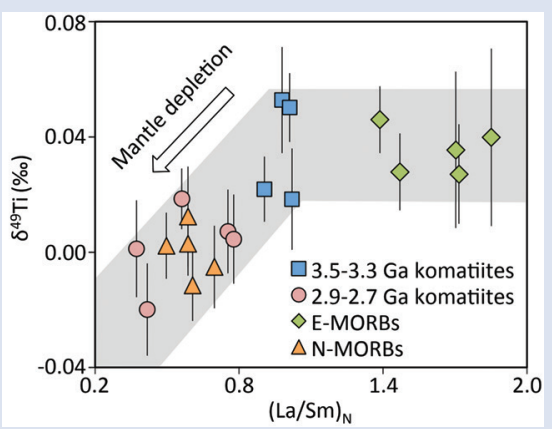

The mechanisms driving the chemical complementarity between depleted MORB mantle (DMM) and continental crust (with an average 'andesitic' composition) remain unclear. By investigating Archean komatiites, and modern enriched (E) and normal (N) MORB samples, we demonstrate that partial melting of the mantle does not fractionate $\mathrm{Ti}$ isotopes, whereas intracrustal differentiation causes significant Ti isotopic fractionation between melts and minerals, specifically Fe-Ti oxides. Thus, Ti isotope ratios are tracers of these two magmatic regimes. N-MORB and late Archean (2.9-2.7 Ga) komatiites are depleted in the heavier $\mathrm{Ti}$ isotopes compared to E-MORB and middle Archean (3.5-3.3 Ga) komatiites. We show that the depletion in the heavier Ti isotopes of the DMM is due to mantle recycling of the isotopically light residues from the generation of felsic continental crust over 3.5-2.7 Ga. This process must have reached a steady state by $\approx 2.5 \mathrm{Ga}$, based on the uniform Ti isotopic composition of contemporary N-MORBs and late Archean komatiites. This change is likely due to a decrease in the mantle potential temperature related to the emergence of plate tectonics.

\section{Introduction}

The Earth's mantle is chemically and isotopically heterogeneous (Allègre, 1982; Zindler and Hart, 1986). Multiple mantle end members, inferred from the radiogenic isotopic compositions ( $\mathrm{Pb}-\mathrm{Pb}, \mathrm{Sm}-\mathrm{Nd}$ and $\mathrm{Rb}-\mathrm{Sr}$ ) of oceanic basalts, have been defined to describe these heterogeneities (Zindler and Hart, 1986). In particular, the depleted MORB mantle (DMM), i.e. the inferred source of the modern normal-type mid-ocean ridge basalts (N-MORB), is characterised by a significant depletion in the incompatible trace elements (Workman and Hart, 2005), and is to a first order compositionally complementary to the continental crust (Hofmann, 1988). Thus, the DMM has been interpreted as a residual mantle that was homogenised after the extraction of a component similar to the present day continental crust (Hofmann, 1988; McCulloch and Bennett, 1994; Workman and Hart, 2005). However, since the continental crust is too silicic to have been derived from a one-step partial melting of upper mantle peridotites, the origin of its complementarity with the DMM is still unclear. Intracrustal magmatic differentiation and removal of the mafic/ultramafic complement are required to drive the bulk continental crust to andesitic compositions (Rudnick, 1995; Walter, 2003).

In order to evaluate the relationship between DMM and the continental crust, quantification of the processes causing the depletions in the incompatible trace element budget of DMM must be understood. Titanium stable isotopes are well suited to discriminate between mantle and crustal melting because they do not appear to fractionate during partial melting of the mantle, whereas they tend to become enriched in the heavier isotopes during magmatic differentiation in the crust (Millet et al., 2016; Greber et al., 2017a,b).

Based on the enrichments of the radiogenic Nd and $\mathrm{Hf}$ isotopes in N-MORB samples (Vervoort et al., 1996; Vervoort and Blichert-Toft, 1999), the DMM should acquire its high Sm/ $\mathrm{Nd}$ and Lu/Hf ratios during the late Archean. Archean komatiites are produced by high degree partial melting (25-40\%) of the mantle, and erupt at temperatures $>1750 \mathrm{~K}$ (Arndt, 2003). These characteristics mitigate chemical and isotopic fractionations during partial melting of their sources, and therefore are sensitive records of the spatio-thermal evolution of the composition of Earth's mantle over their eruptive history (Walter, 2003; Puchtel et al., 2009; Sossi et al., 2016). In contrast with Archean komatiites, MORB samples are derived from lower degrees of partial melting (5-15\%) of the modern upper mantle (Asimow and Langmuir, 2003; Workman and Hart, 2005), and are subdivided based on their concentration in incompatible elements from light rare earth element depleted (N-MORB) to enriched (E-MORB) (Workman and Hart, 2005).

Here we present a high precision Ti isotopic study of Archean komatiites, and N-MORB and E-MORB. The comparison of the Ti isotopic composition of MORBs with that of Archean komatiites is used to confirm isotopic effects by partial melting of the mantle, and further trace Ti isotopic variations in the mantle since the Archean.

\footnotetext{
1. Institut de Physique du Globe de Paris, Université Paris Diderot, Université Sorbonne Paris Cité, CNRS UMR 7154, 1 rue Jussieu, 75005, Paris, France

2. Institut Universitaire de France, Paris, France

* Corresponding author (email: deng@ipgp.fr)
} 


\section{Results}

Ti Isotopic Variations in the Archean and Modern Mantle-Derived Rocks. Individual komatiites and MORBs have $\delta^{49} \mathrm{Ti}$ (the per mille deviation of the ${ }^{49} \mathrm{Ti} /{ }^{47} \mathrm{Ti}$ ratio relative to the OL-Ti standard) values between $+0.053 \pm 0.018 \%$ ond $-0.020 \pm 0.016 \%$ o (Tables S-1 and S-2). On average, N-MORB samples are isotopically lighter $\left(\delta^{49} \mathrm{Ti}=+0.001 \pm 0.008 \%\right.$; 2 se, $\mathrm{n}=5)$ than E-MORB samples $\left(\delta^{49} \mathrm{Ti}=+0.035 \pm 0.007 \%\right.$; 2 se, $\mathrm{n}=5)$. Similarly, among Archean komatiites, the late Archean (2.9-2.7 Ga) ones, which are depleted in incompatible trace elements, have a lower average $\delta^{49} \mathrm{Ti}$ value $(+0.003 \pm 0.013 \%$, 2 se, $\mathrm{n}=5$ ) than the middle Archean (3.5-3.3 Ga) ones $\left(\delta^{49} \mathrm{Ti}=+0.038 \pm 0.018 \%\right.$; 2 se, $\left.\mathrm{n}=4\right)$, which have primitive mantle-like trace element abundances (Fig. 1). The Ti isotopic composition of the middle Archean komatiites overlaps with the average composition of the 12 chondrite groups $\left(\delta^{49} \mathrm{Ti}=\right.$ $+0.070 \pm 0.054 \%$ o, $2 \mathrm{sd}, \mathrm{n}=12$; Deng et al., 2018) but is lower than that of the continental crust as inferred from shale data $\left(\delta^{49} \mathrm{Ti}=+0.181 \pm 0.015 \%\right.$ o, $2 \mathrm{se}, \mathrm{n}=78$; Greber et al., 2017b) (Fig. 2). These observations imply the presence of either Ti isotopic heterogeneities in the mantle or $\mathrm{Ti}$ isotopic fractionations during partial melting and fractional crystallisation, or both.

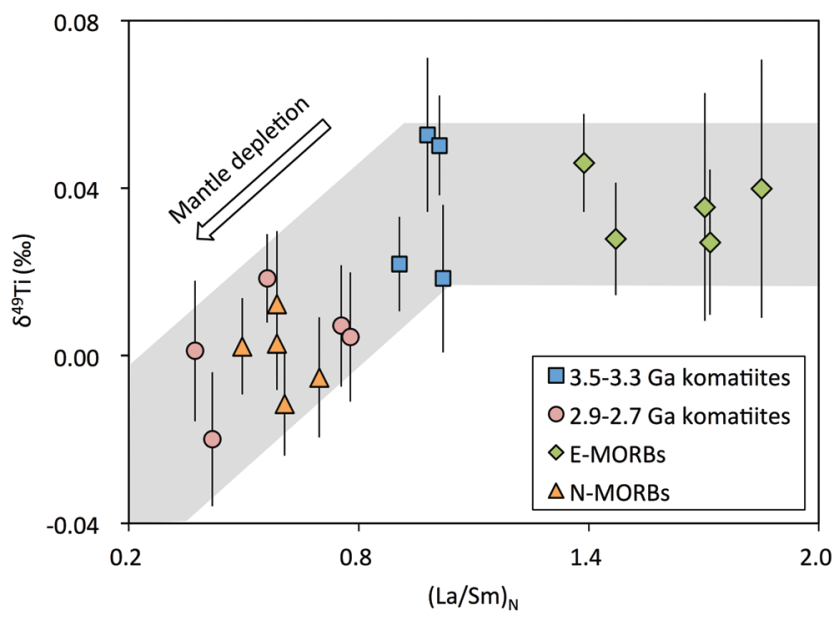

Figure 1 Positive correlation between $\delta^{49} \mathrm{Ti}$ and $(\mathrm{La} / \mathrm{Sm})_{\mathrm{N}}$ values for the komatiite and MORB samples.

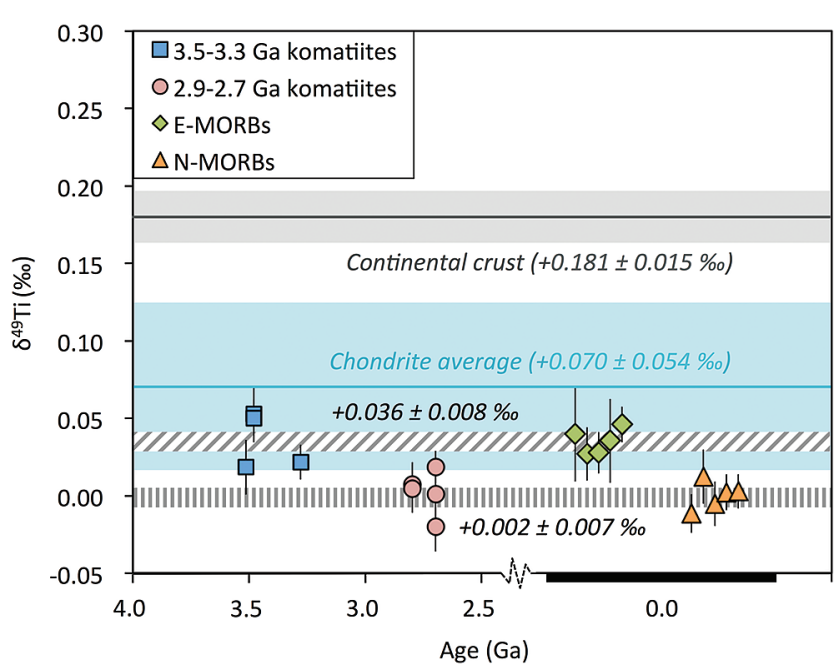

Figure 2 The change of $\delta^{49} \mathrm{Ti}$ values with time for the komatiite and MORB samples. The average $\delta^{49} \mathrm{Ti}$ values for the depleted and primitive groups are indicated. Also shown are the average of 12 chondrite groups with 2 sd uncertainty from Deng et al. (2018) and the continental crust value inferred from shale data from Greber et al. (2017b).

\section{Discussion}

Ti Isotopic Compositions of the Mantle Sources of Archean Komatiites. Two arguments demonstrate that Archean komatiites have inherited the Ti isotopic compositions of their mantle sources. (i) Komatiites were produced by high degree partial melting (25-40\%) at mantle potential temperature $>2000 \mathrm{~K}$ (Arndt, 2003; Sossi et al., 2016), which minimises potential Ti isotopic fractionation between komatiitic liquids and their sources. (ii) The fractional crystallisation of olivine at low pressure does not produce significant $\mathrm{Ti}$ isotopic fractionation in the residual melts, because $\mathrm{Ti}$ is incompatible in olivine (Sossi and O'Neill, 2016). Thus, the change of Ti isotopic composition of komatiites with time reflects a secular depletion in the heavier $\mathrm{Ti}$ isotopes of the mantle during the mid-late Archean (Fig. 2). The timing of this change in the Ti isotopic composition of the mantle matches the formation age of the DMM inferred from the Sm-Nd and Lu-Hf isotope compositions of juvenile crustal rocks of various ages (Vervoort et al., 1996; Vervoort and Blichert-Toft, 1999). In addition, late Archean komatiites have a trace element inventory similar to that of the DMM (Workman and Hart, 2005; Sossi et al., 2016), e.g., $(\mathrm{La} / \mathrm{Sm})_{\mathrm{N}}$ values of $0.37-0.78$ where the subscript ' $\mathrm{N}$ ' denotes normalisation to the primitive mantle (McDonough and Sun 1995). Thus, the late Archean komatiites have likely sampled a mantle reservoir that has experienced melt extraction, potentially causing its Ti isotopic composition to trend towards that of the contemporary DMM.

Lack of Resolvable Ti Isotopic Fractionation during the Genesis of MORB Melts. Differentiated magmas tend to be enriched in the heavier $\mathrm{Ti}$ isotopes as a result of the preferential incorporation of the lighter Ti isotopes into the VI-fold sites of Fe-Ti oxides, relative to the lower-coordinated ones (more IV- and V-fold) of the silicate melts (Millet et al., 2016). Following a similar rationale, Ti isotopes may be also fractionated during the generation of MORB melts or their subsequent differentiation. However, the magnitude of this isotopic fractionation cannot be assessed precisely from previous data or from theoretical considerations: additional experimental or theoretical work would be required to quantify these effects precisely. In the following, we estimate the magnitude of this fractionation from the present $\delta^{49} \mathrm{Ti}$ data from the MORB and komatiite samples.

Assuming a Rayleigh distillation process for the extraction of MORB melts, which is consistent with near-fractional melting (Asimow et al., 1997), the $\delta^{49} \mathrm{Ti}$ difference of the melting residues or the partial melts relative to their sources, hereafter referred respectively as $\Delta^{49} \mathrm{Ti}_{\text {residue-source }}$ and $\Delta^{49} \mathrm{Ti}_{\text {melt-source, }}$ should follow:

$$
\Delta^{49} \mathrm{Ti}_{\text {residue-source }}=10^{3} \times \ln \left(\alpha_{\text {melt-crystal }}^{49 / 47}\right) \times \ln (f)(\text { Eq. } 1)
$$

and

$$
\Delta^{49} \mathrm{Ti}_{\text {melt-source }}=-10^{3} \times \ln \left(\alpha_{\text {melt-crystal }}^{49 / 47}\right) \times \ln (f) \times \frac{f}{1-f}(\text { Eq. } 2),
$$

where $f$ is the remaining Ti fraction in the melting residues and $\alpha_{\text {melt-crustal }}^{49 / 47}$ is the melt-crystal Ti isotopic fractionation factor defined as:

$$
\alpha_{\text {melt-crystal }}^{49 / 47}=\frac{\left({ }^{49} \mathrm{Ti} /{ }^{47} \mathrm{Ti}\right)_{\text {melt }}}{\left({ }^{49} \mathrm{Ti} /{ }^{47} \mathrm{Ti}\right)_{\text {crystal }}}
$$

The remaining Ti fraction in the melting residues can be simply modelled by a fractional melting process:

$$
f=(1-F)^{1 / D_{T i}}
$$


(i)

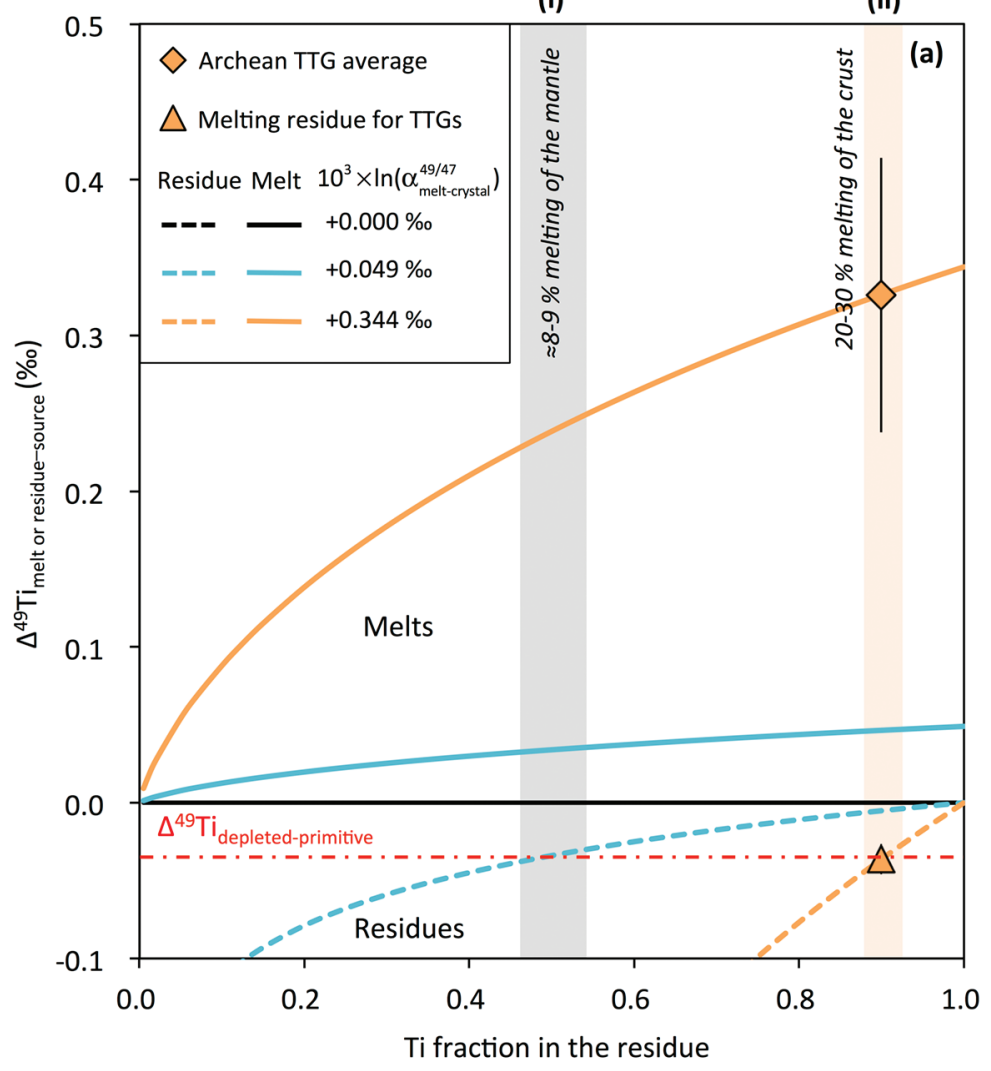

(b)

(i) Partial melting of the mantle

$\mathrm{D}_{\mathrm{T}} \approx 0.132, \mathrm{~F} \approx 8-9 \%$

$\approx 50 \%$ Ti remaining in the residue

$\delta^{49} \mathrm{Ti}_{\text {Basalt }}-\delta^{49} \mathrm{Ti}_{\text {Residual mantle }} \approx 0 \%$

Basalt

(ii) Partial melting of the crust

$\mathrm{D}_{\mathrm{Ti}} \approx 3.2-3.3, \mathrm{~F} \approx 20-30 \%$

$\approx 90 \%$ Ti remaining in the residue

Residual 11 is $\delta^{49} \mathrm{Ti}_{\text {Felsic melt }}-\delta^{49} \mathrm{Ti}_{\text {Residue }} \approx+0.344 \%$

mantle

i

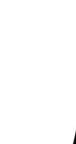

Felsic

continental

crust

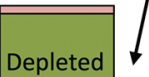

MORB

mantle

Recycling into the mantle

Figure 3 Modelling the Ti isotopic fractionations in the partial melts and residues from partial melting of the mantle or the crust. The grey area in (a) indicates the remaining Ti fraction in the residual mantle after $\approx 8-9 \%$ partial melting $\left(D_{\text {Ti }} \approx 0.132 ;\right.$ Prytulak and Elliott, 2007), i.e. process (i) illustrated in (b). The orange field in a shows the Ti fraction after 20 -30\% partial melting of a basaltic crust to produce the felsic melts equivalent to tonalite-trondhjemite-granodiorite (TTGs) ( $\mathrm{D}_{\mathrm{Ti}} \approx 3.2-3.3$; Martin et al., 2014), i.e. process

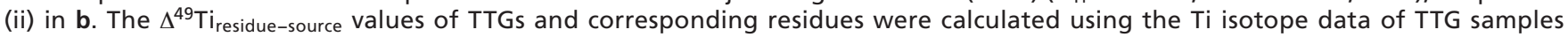
from Greber et al. (2017b) and assuming E-MORBs as their sources.

where $F$ is the melt fraction and $D_{T i}$ is the partition coefficient of Ti. The values of $F$ and $D_{T i}$ are estimated based on experimental data. To define the value of $10^{3} \times \ln \left(\alpha_{\text {melt-crustal }}^{49 / 47}\right)$, the Ti isotopic ratios of the sources are compared to that of the partial melts or of the melting residues, i.e. the values of $\Delta^{49} \mathrm{Ti}_{\text {melt-source }}$ or of $\Delta^{49} \mathrm{Ti}_{\text {residue-source }}$ need to be determined.

During partial melting of mantle peridotites, Ti is a moderately incompatible element $\left(\mathrm{D}_{\mathrm{Ti}} \approx 0.132\right.$ for spinel peridotite; Prytulak and Elliott, 2007). The genesis of MORB melts $(F=5-15 \%)$ should thus extract $\approx 33-71 \%$ of the Ti from the source regions (Equation 4; Asimow and Langmuir, 2003; Workman and Hart, 2005). Using $f=0.5$ (i.e. a mean $F \approx 8.7 \%$ ) in Equation 2, the value of $\Delta^{49} \mathrm{Ti}_{\text {melt-source }}$ for MORBs is:

$$
\Delta^{49} T i_{\text {melt-source }} \approx 0.69 \times 10^{3} \times \ln \left(\alpha_{\text {melt-crystal }}^{49 / 47}\right) \text { (Eq. 5). }
$$

Taking the Ti isotopic compositions of the late Archean komatiites as representative of the DMM, $\Delta^{49} \mathrm{Ti}_{\text {melt-source }}$ is equal to $\Delta^{49} \mathrm{Ti}_{\mathrm{N}-\mathrm{MORB}}$-late Archean komatiite $=-0.002 \pm 0.015 \%$ o $(2 \mathrm{se})$. This corresponds to $10^{3} \times \ln \left(\alpha_{\text {melt }- \text { crystal }}^{49 / 47}\right)=-0.003 \pm 0.022 \%$ (2 se) (Fig. 1).

The lack of significant Ti isotopic fractionation between crystal and melt during mantle melting raises a question about the origin of the $\mathrm{Ti}$ isotopic difference between the depleted and primitive mantle reservoirs $\left(\Delta^{49} \mathrm{Ti}_{\text {depleted-primitive }}\right.$ $=-0.034 \pm 0.011 \%$; Fig. 2). Based on its average $\mathrm{TiO}_{2}$ content $(\approx 0.119$ wt. \%), the DMM would be at a maximum $50 \%$ depleted in Ti relative to the primitive mantle $(\approx 0.217$ wt. \%)
(McDonough and Sun, 1995; Workman and Hart, 2005). To produce a $\Delta^{49} \mathrm{Ti}_{\text {depleted-primitive }}=-0.034 \pm 0.011 \%$ would require a $10^{3} \times \ln \left(\alpha_{\text {melt }- \text { crystal }}^{49 / 4}\right)$ of $+0.049 \pm 0.016 \%$ using $f=0.5$ in Equation 1 which is too high compared to the limited $10^{3} \times \ln \left(\alpha_{\text {melt-crystal }}^{49 / 47}\right)$ value during partial melting of the mantle peridotites (Fig. 3). Thus, another mechanism is required to explain the Ti isotopic difference between the depleted and primitive mantle reservoirs.

Recycling of Melting Residues from the Generation of the Continental Crust into the Late Archean Mantle. In contrast with the lack of melt-crystal Ti isotopic fractionation during partial melting of the peridotitic mantle, magma differentiation in the crust produces significant Ti isotopic variations (Fig. 2; Millet et al., 2016; Greber et al., 2017a,b). Significant volumes of felsic plutonic rocks, i.e. TTGs, have been generated in the late Archean (Martin, 1986). Contemporaneously, the $\delta^{49} \mathrm{Ti}$ value of the mantle is observed to have changed, as indicated by komatiities. These TTGs likely originate from partial melting of protoliths of basaltic compositions (Martin et al., 2014). Since Ti-rich minerals are stable under crustal temperatures and pressures, $\mathrm{Ti}$ acts as a compatible element during melt-crystal fractionation in the crust, e.g., $D_{T i} \approx 3.2-3.3$ (Martin et al., 2014). The generation of TTG-like melts would then extract only $\approx 10 \%$ of Ti from the sources, using $F=$ 0.20-0.30 and $D_{T i}=3.2-3.3$ in Equation 4. The 2.98 Ga TTGs from Kaapvaal Craton have been shown to be significantly heavier in $\mathrm{Ti}$ isotopes than mantle-derived rocks $\left(\delta^{49} \mathrm{Ti}=\right.$ $+0.361 \pm 0.088 \%$ o, 2 se, $\mathrm{n}=10$; Greber et al., 2017b). Assuming a source with an E-MORB-like isotopic composition, these 
TTGs indicate a $\Delta^{49} \mathrm{Ti}_{\text {melt-source }} \approx+0.326 \pm 0.088 \%$, corresponding to a $\Delta^{49} \mathrm{Ti}_{\text {residue-source }} \approx-0.036 \pm 0.010 \%$ o and a $10^{3} \times \ln \left(\alpha_{\text {melt }- \text { crystal }}^{49 / 47}\right) \approx+0.344 \pm 0.093 \%$ o when using $f=0.9$ in Equations 1 and 2 (Fig. 3).

The much larger Ti isotopic fractionation produced during partial melting of crust, compared to partial melting of peridotites, likely arises from the facts that: (i) melt-crystal segregation in the crust occurs at lower temperatures $(<1273$ $\mathrm{K})$ than that of the normal decompression melting of the mantle ( $\geq 1673 \mathrm{~K}$ ) (Martin et al., 2014), and (ii) Ti is more IVand V-fold coordinated in silicic melts than in mafic melts (Farges et al., 1996). These thermal and structural differences significantly increase $10^{3} \times \ln \left(\alpha_{\text {melt-crystal }}^{49 / 47}\right)$ during the genesis of TTG-like melts. As a consequence, the residues (cumulates or restites) would be enriched in the lighter Ti isotopes with a $\Delta^{49} \mathrm{Ti}_{\text {residue-source }} \approx-0.036 \pm 0.010 \%$. Thus, the lighter $\mathrm{Ti}$ isotopic compositions of the DMM relative to the primitive mantle reservoirs could be due to mantle recycling of the residues from the generation of the late Archean felsic continental crust. To produce a $\delta^{49} \mathrm{Ti}$ difference of $0.034 \%$ o between E-MORBs and N-MORBs, an addition of $\geq 3 \%$ shale-like sediments $\left(\mathrm{TiO}_{2} \approx 0.64\right.$ wt. $\%$ and $\delta^{49} \mathrm{Ti} \approx+0.18 \%$; Greber et al., $2017 \mathrm{~b})$ into the $\mathrm{DMM}\left(\mathrm{TiO}_{2} \approx 0.12\right.$ wt. $\%$ and $\delta^{49} \mathrm{Ti} \approx+0.00$ $\%$ o) would be needed, which is unlikely since E-MORBs have only slightly higher ${ }^{87} \mathrm{Sr} /{ }^{86} \mathrm{Sr}$ and lower ${ }^{143} \mathrm{Nd} /{ }^{144} \mathrm{Nd}$ ratios than N-MORBs (Workman and Hart, 2005). Therefore, we consider that E-MORBs are derived from a less depleted mantle reservoir that has not been subjected to crustal residue recycling rather than the one contaminated by recycled sediments.

Since the DMM $\left(\Delta^{49} \mathrm{Ti}_{\text {depleted-primitive }}=-0.034 \pm 0.011 \%\right.$ o $)$ seems to inherit the Ti isotopic composition of the residues from the formation of the late Archean TTGs $\left(\Delta^{49} \mathrm{Ti}_{\text {residue-source }}\right.$ $\approx-0.036 \pm 0.010 \%$; Fig. 3a), a significant proportion of $\mathrm{Ti}$ $(94 \pm 40 \%)$ in the DMM (i.e. $\left.f_{T i-D M M}\right)$ must have been processed by magma differentiation in the crust, if following the relation of $f_{T i-D M M}=\frac{\Delta^{49} T i_{\text {depleted-primitive }}}{\Delta^{49} T i_{\text {residue-source }}}$. This would require that, during middle to late Archean, basaltic crust having the Ti isotopic composition of the mantle was (i) continuously extracted, and (ii) re-melted to produce a felsic continental crust, with the residues from this process being mixed into the upper mantle (Fig. 3b). The delivery of melting residues from the crust into the mantle can be achieved by either slab subduction (Martin, 1986) or lower crustal recycling (Rudnick, 1995). If the late Archean depleted mantle contained $20 \%$ by mass of the bulk silicate Earth (BSE) (McCulloch and Bennett, 1994), the Ti isotope variations in the mantle would be produced by the extraction of a felsic continental crust constituting $\approx 0.38-0.56 \%$ mass of the BSE during 3.5-2.7 Ga. Future Ti isotopic studies of komatiites and basalts covering the full age range of 3.5-2.7 Ga may be useful to test whether the continental extraction was continuous or abrupt. In the Archean, the hot convective mantle could homogenise the recycled melting residues into the ambient mantle. However, this mechanism should stop operating after the Archean, since the DMM was formed in the late Archean and has been stable in the upper mantle till the present day (Fig. 2). As the felsic continental crust continued to grow after the Archean (Dhuime et al., 2015), additional Ti isotope heterogeneities may exist in the mantle due to the recycling of ultramafic or mafic residues from the crust, which may be later sampled by intraplate magmas. Overall, the Earth's change across the Archean-Proterozoic boundary may be due to the decrease in the thermal gradient of the mantle (Korenaga, 2013), likely signifying the prevalence of plate tectonics (Dhuime et al., 2015; Tang et al., 2016).

\section{Acknowledgements}

We thank John Creech for introducing IsoSpike, Manuel Moreira for providing the MORB samples, and Marc-Alban Millet for sharing OL-Ti standard. Kirsten van Zuilen is thanked for her help in the lab. FM acknowledges funding from the ERC under the H2020 framework programme/ ERC grant agreement \#637503 (Pristine). FM and MC thank the financial support of the UnivEarthS Labex programme at Sorbonne Paris Cité (ANR-10-LABX-0023 and ANR-11IDEX-0005-02). Parts of this work were supported by IPGP multidisciplinary programme PARI, and by Region Île-deFrance SESAME Grant no. 12015908.

Editor: Cin-Ty Lee

\section{Additional Information}

Supplementary Information accompanies this letter at http:// www.geochemicalperspectivesletters.org/article1831.

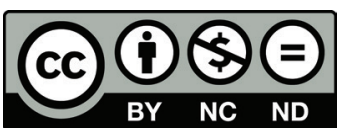

This work is distributed under the Creative Commons Attribution Non-Commercial No-Derivatives 4.0 License, which permits unrestricted distribution provided the original author and source are credited. The material may not be adapted (remixed, transformed or built upon) or used for commercial purposes without written permission from the author. Additional information is available at http://www.geochemicalperspectivesletters.org/ copyright-and-permissions.

Cite this letter as: Deng, Z., Moynier, F., Sossi, P.A., Chaussidon, M. (2018) Bridging the depleted MORB mantle and the continental crust using titanium isotopes. Geochem. Persp. Let. 9, 11-15.

\section{References}

AllÈGRE, C.J. (1982) Chemical geodynamics. Tectonophysics 81, 109-132.

ARNDT, N. (2003) Komatiites, kimberlites, and boninites. Journal of Geophysical Research: Solid Earth 108, doi: 10.1029/2002JB002157.

Asimow, P.D., LANGMUIR, C.H. (2003) The importance of water to oceanic mantle melting regimes. Nature 421, 815-820.

Asimow, P.D., HirschmanN, M.M., StolPer, E.M. (1997) An analysis of variations in isentropic melt productivity. Philosophical Transactions of the Royal Society of London A 355, 255-281.

Deng, Z., Moynier, F., van Zuilen, K., Sossi, P.A., Pringle, E.A., CHAussidon, M. (2018) Lack of resolvable titanium stable isotopic variations in bulk chondrites. Geochimica et Cosmochimica Acta 239, 409-419.

Dhuime, B., Wuestefeld, A., HaWkesworth, C.J. (2015) Emergence of modern continental crust about 3 billion years ago. Nature Geoscience 8 , $552-555$.

FARGeS, F., Brown JR, G.E., ReHr, J.J. (1996) Coordination chemistry of Ti (IV) in silicate glasses and melts: I. XAFS study of titanium coordination in oxide model compounds. Geochimica et Cosmochimica Acta 60, 3023-3038

Greber, N.D., Dauphas, N., Puchtel, I.S., Hofmann, B.A., Arndt, N.T. (2017a) Titanium stable isotopic variations in chondrites, achondrites and lunar rocks. Geochimica et Cosmochimica Acta 213, 534-552.

Greber, N.D., Dauphas, N., BeKker, A., PtáČek, M.P., Bindeman, I.N., HofmanN, A. (2017b) Titanium isotopic evidence for felsic crust and plate tectonics 3.5 billion years ago. Science 357, 1271-1274

HofmanN, A.W. (1988) Chemical differentiation of the Earth: the relationship between mantle, continental crust, and oceanic crust. Earth and Planetary Science Letters 90, 297-314.

KorEnAGA, J. (2013) Initiation and evolution of plate tectonics on Earth: theories and observations. Annual Review of Earth and Planetary Sciences 41, 117-151. 
MARTIN, H. (1986) Effect of steeper Archean geothermal gradient on geochemistry of subduction-zone magmas. Geology 14, 753-756.

Martin, H., Moyen, J.F., Guitreau, M., Blichert-Toft, J., Le Pennec, J.L. (2014) Why Archean TTG cannot be generated by MORB melting in subduction zones. Lithos 198, 1-13.

McCulloch, M.T., BennetT, V.C. (1994) Progressive growth of the Earth's continental crust and depleted mantle: geochemical constraints. Geochimica et Cosmochimica Acta 58, 4717-4738.

McDonough, W.F., Sun, S.S. (1995) The composition of the Earth. Chemical Geology 120, 223-253.

Millet, M.A., Dauphas, N., Greber, N.D., Burton, K.W., Dale, C.W., Debret, B., Macpherson, C.G., Nowell, G.M., Williams, H.M. (2016) Titanium stable isotope investigation of magmatic processes on the Earth and Moon. Earth and Planetary Science Letters 449, 197-205.

PRYTUlAK, J., ElLIOTT, T. (2007) $\mathrm{TiO}_{2}$ enrichment in ocean island basalts. Earth and Planetary Science Letters 263, 388-403.

Puchtel, I.S., Walker, R.J., Brandon, A.D., Nisbet, E.G. (2009) Pt-Re-Os and Sm-Nd isotope and HSE and REE systematics of the 2.7 Ga Belingwe and Abitibi komatiites. Geochimica et Cosmochimica Acta 73, 6367-6389.

RUDNICK, R.L. (1995) Making continental crust. Nature 378, 571-578.

Sossi, P.A., O'NeILL, H.S.C. (2016) Liquidus temperatures of komatiites and the effect of cooling rate on element partitioning between olivine and komatiitic melt. Contributions to Mineralogy and Petrology 171, 49. doi: 10.1007/s00410-016-1260-x.

Sossi, P.A., Eggins, S.M., Nesbitt, R.W., Nebel, O., Hergt, J.M., CamPBell, I.H., O'NeIll, H.S.C., VAn KRAnENDONK, M., DaVIES, D.R. (2016) Petrogenesis and geochemistry of Archean komatiites. Journal of Petrology 57, 147-184.

TANG, M., Chen K., Rudnick, R.L. (2016) Archean upper crust transition from mafic to felsic marks the onset of plate tectonics. Science 351 372-375.

Vervoort, J.D., BLichert-Toft, J. (1999) Evolution of the depleted mantle: $\mathrm{Hf}$ isotope evidence from juvenile rocks through time. Geochimica et Cosmochimica Acta 63, 533-556.

Vervoort, J.D., Patchett, P.J., Gehrels, G.E., Nutman, A.P. (1996) Constraints on early Earth differentiation from hafnium and neodymium isotopes. Nature 379, 624-627.

WALTER, M.J. (2003) Melt extraction and compositional variability in mantle lithosphere. In: Carlson, R.W. (Ed.) Treatise on Geochemistry-The Mantle and Core. Elsevier-Pergamon, Oxford, 363-394.

WORKMAN, R.K., HART, S.R. (2005) Major and trace element composition of the depleted MORB mantle (DMM). Earth and Planetary Science Letters 231, 53-72.

Zindler, A., HART, S. (1986) Chemical geodynamics. Annual Review of Earth and Planetary Sciences 14, 493-571. 